Received Date : 14-Jan-2014

Revised Date : 21-Jul-2014

Accepted Date : 22-Jul-2014

Article type : Review Article

\title{
Preoptic inputs and mechanisms that regulate maternal responsiveness
}

\author{
A. Dobolyi ${ }^{1,2}$, D.R. Grattan ${ }^{3}$, D. S. Stolzenberg ${ }^{4}$
}

${ }^{1}$ Laboratory of Molecular and Systems Neurobiology, Institute of Biology, NAP-Hungarian Academy of Sciences and Eötvös Loránd University, Budapest, Hungary

${ }^{2}$ Laboratory of Neuromorphology, Department of Anatomy, Histology and Embryology, Semmelweis University, Budapest, Hungary

${ }^{3}$ Department of Anatomy and Centre for Neuroendocrinology, School of Medical Sciences, University of Otago, Dunedin, New Zealand

${ }^{4}$ Department of Psychology, University of California, David CA, USA

Corresponding Authors:

Prof. Arpad Dobolyi, Laboratory of Molecular and Systems Neurobiology, Institute of Biology, Eötvös Loránd University, Pázmány Péter sétány 1C, Budapest 1117, Hungary email: dobolyi.arpad@med.semmelweis-univ.hu Danielle S. Stolzenberg, Department of Psychology, 135 Young Hall, University of California Davis, CA 95616, USA

Email: Danielle.stolzenberg@gmail.com

Short title: Preoptic mechanisms of maternal responsiveness

Key words: maternal motivation, and maternal behaviour, medial preoptic area of hypothalamus, epigenetics, postpartum period

This article has been accepted for publication and undergone full peer review but has not been through the copyediting, typesetting, pagination and proofreading process, which may lead to differences between this version and the Version of Record. Please cite this article as doi: 10.1111/jne. 12185

This article is protected by copyright. All rights reserved. 


\begin{abstract}
The preoptic area is a well-established centre for the control of maternal behaviour. An intact medial preoptic area (MPOA) is required for maternal responsiveness as lesion of the area abolishes maternal behaviours. Whereas hormonal changes in the peripartum period contribute to the initiation of maternal responsiveness, inputs from pups are required for its maintenance. Neurones are activated in different parts of the MPOA in response to pup exposure. In the present review, we summarize the potential inputs to the MPOA of rodent dams from the litter that can activate MPOA neurones. The roles of potential indirect effects through increased prolactin levels, as well as neuronal inputs to the preoptic area are described. Recent results on the pathway mediating the effects of suckling to the MPOA suggest that neurones containing the neuropeptide tuberoinfundibular peptide of 39 residues in the posterior thalamus are candidates to convey the suckling information to the MPOA. Although the molecular mechanism through which these inputs alter MPOA neurones to support the maintenance of maternal responding is not yet known, altered gene expression is a likely candidate. Here, we summarize gene expression changes in the MPOA that have been linked to maternal behaviour and explore the idea that chromatin remodelling during motherinfant interactions mediates the long-term alterations in gene expression that sustain maternal responding.
\end{abstract}

\title{
Introduction
}

All mammalian infants are incapable of surviving on their own. Thus, infant survival depends on the quality of care infants receive from birth until weaning. In most mammals, the mother provides the constant care required for successful infant growth, development, and survival, and hence the initiation of maternal behaviour after birth is critical (1). The most extensive experimental investigations of maternal behaviours have been performed in rodents. Rat and mouse dams display a variety of specific caregiving behaviours that start around the time of parturition: they consume placenta, foetal membranes and fluids, build a nest to keep pups warm and retrieve displaced pups there, lick the pups and nurse them in characteristic postures (2). In addition, mothers demonstrate reduced anxiety and increased aggression towards intruders approaching their nest [in this issue, (3)]. Although there is considerable overlap in how mothers respond to their infants, there are some species differences in specific caregiving behaviours. Thus, this review focuses on the mechanisms that underlie maternal motivation, or the shift in responsiveness toward infants, rather than mechanisms that regulate individual maternal behaviours (2).

This article is protected by copyright. All rights reserved. 
The transition into motherhood is comprised of a dramatic shift in maternal responsiveness, which allows mothers to spend a considerable period of time devoting their energy toward rearing offspring. Some species, such as rats, are relatively unresponsive to infants before motherhood; therefore, this shift may involve a decrease in aversion toward infants coupled with an increase in attraction toward infants $(4,5)$. In other species, such as mice, where unrelated individuals do respond to infants, this shift may exclusively involve an increase in infant attraction. In all species studied, including humans, the hormonal events of pregnancy and parturition function to increase maternal motivation, or responsiveness toward infants, at birth (6). At birth, mothers are so highly motivated to interact with their offspring that they will traverse an anxiogenic, novel environment (such as a novel T-maze) or learn to press a lever to interact with pups (7-11). The elevated estrogen / progesterone ratio, which occurs at the end of pregnancy, plays a crucial role in this process (12-19). When motherinfant interaction occurs in this hormonal context, maternal motivation is initiated and sustained for extended periods of time (20-22).

Although hormonal stimulation potentiates maternal motivation, it is the experience of interacting with infants at the time of birth that is necessary for the initiation and maintenance of maternal care. Three pieces of information support this idea. First, maternal motivation remains high during the postpartum period long after the elevated estradiol/progesterone ratio associated with birth has waned $(23,24)$. The level of ovarian steroid hormones is very low at 10 days of postpartum, when maternal behaviours are maximal (25). Thus, these hormones might prime neural circuits for the receipt of infant stimuli, but hormonal stimulation does not sustain maternal care. Second, non-hormonal factors must also be operating in those cases where paternal behaviour or alloparental behaviour occurs [in this issue, (26)], since these individuals are not exposed to the hormonal changes associated with pregnancy although exposure to pups may induce some hormonal changes in these individuals [in this issue, (27)]. In support of this idea, maternal responsiveness can occur in the absence of pregnancy hormone stimulation after continual exposure to infant stimuli, in a process termed sensitization (28). Sensitization can occur in mice that lack the aromatase enzyme, and are therefore incapable of synthesizing oestradiol $(7,29)$. Thus, estradiol stimulation is not required for maternal responsiveness. Third, experience-induced changes in maternal motivation extend far beyond weaning. Thus, once a female has interacted with pups, maternal motivation is "permanently" altered. For example, in rats, the future onset of maternal behaviour is less dependent on hormone stimulation (20-22). In laboratory strains of

This article is protected by copyright. All rights reserved. 
mice, which do not depend on hormone stimulation to care for pups, females will continue to rescue pups from an anxiogenic environment (novel T-maze) (30,31). The amount of experience with pups required to permanently alter maternal motivation varies depending on species and hormonal profile. For example, in postpartum rats as little as 15 minutes of mother-infant interaction maintains subsequent maternal responsiveness even during long periods of separation from pups (20). In pup-naive, virgin female mice, 2 hours of interaction for 4 consecutive days increases maternal responding on a T-maze up to one month later (29). Therefore, the transition into motherhood involves the consolidation of maternal learning and the maintenance of a maternal memory $(22,32)$.

One proposal is that there is a core neural circuit regulating parental behaviour in all mammals of both sexes (1), but whether infant stimuli can act on this circuit to elicit responsiveness depends on how developmental, hormonal, and/or experiential factors impact this circuit [in this issue, (33)]. The medial preoptic area (MPOA) is a critical site within this circuit, which receives pup-related inputs from all sensory modalities and coordinates maternal responsiveness through its widespread projections (4,34-36). Hormonal and/or experiential factors can prime the MPOA for increased responsiveness toward pup-related inputs. For example, somatosensory inputs derived from the pups play an important role in the onset of maternal behaviour, as well as the long-term maintenance of maternal responding $(24,37,38)$. In this review, we focus on the hormonal and neuronal inputs that activate the MPOA during mother-infant interaction, as well as the subsequent genetic and epigenetic changes that may contribute to the long-term maintenance of maternal responding.

\section{The medial preoptic area}

The MPOA is situated in the medial zone of the rostral region of the hypothalamus. Its major structure is the medial preoptic nucleus, which consists of central, medial and lateral subdivisions (39). The central and medial subdivisions of the medial preoptic nucleus overlap with the sexually dimorphic nucleus, which is considerably larger in males than in females $(40,41)$. In this review, we also include the dorsolaterally adjacent ventral subdivision of the bed nucleus of the stria terminalis (vBNST) in the term MPOA because it receives similar inputs and plays a similar role in maternal responsiveness. Furthermore, a clear separation of these areas was not found cytoarchitectonically (42). Accepted brain atlases actually show the parastrial nucleus between them (43) while some researchers place the anterior (or lateral)

This article is protected by copyright. All rights reserved. 
subcommissural nucleus to the border of the medial preoptic area and the vBNST to describe the location of oxytocinergic neurones in the area $(44,45)$.

A number of different approaches have been used to examine the role of the preoptic area in the regulation of maternal behaviour. Extensive evidence from this work indicates that the preoptic area plays a crucial role in the initiation and maintenance of maternal behaviours. Large electrical as well as axon-sparing excitotoxic lesions of the MPOA eliminate all maternal behaviours without affecting other, e.g. feeding behaviours (46,47). Temporal pharmacological inactivation of MPOA produces similar effects $(48,49)$. Small bilateral lesions of the dorsal MPOA, but not the sexually dimorphic nucleus, were sufficient to abolish nest building and retrieving in rat (50). In mice, the lesions the central MPOA (a potentially similar area) were the most effective in eliminating maternal behaviours (51). In contrast, electrical stimulation of the MPOA increased maternal responsiveness (52).

The MPOA must receive sensory information from the litter to regulate maternal responsiveness (5). Sensory information reaches the MPOA through neuronal inputs. Interaction with the litter can also have effects on MPOA activity mediated by hormones. For example, suckling stimulation affects the central and peripheral release of oxytocin and prolactin, which bind to receptors in the MPOA to regulate maternal responding.

\section{Prolactin as a regulator of preoptic neurones in mothers}

There is a strong body of findings that support a role for prolactin in the central stimulation of the onset of maternal behaviour. Central nervous system actions of prolactin in regulating parental behaviours were first identified in the early 1960's, when prolactin was implicated in brooding behaviour in birds (53), nest building behaviour in rabbits $(54,55)$ and fin-fanning behaviour in some fish to induce fresh water flow over their eggs (56). Much work has subsequently characterized the role of prolactin in rodent models, particularly in rats. As described above, maternal care can be induced in virgin female rats with repeated exposure to pups, albeit with a latency period of several days (28). Bridges and colleagues found that this latency period could be markedly shortened when gonadectomised, virgin rats were treated sequentially with progesterone followed by estradiol (57). As well as stimulating a rapid onset of maternal care towards foster young, this steroid regimen significantly elevated serum prolactin levels. When steroid-treated females were concurrently treated with bromocriptine to suppress endogenous prolactin secretion, the onset of maternal behaviour towards foster young was again delayed from a latency of 1-2 days to 4-5 days (58), strongly implicating prolactin as a key mediator of the enhanced onset of maternal care. These behavioural effects

This article is protected by copyright. All rights reserved. 
of prolactin can be mimicked by placental lactogen (59). Prolactin actions on maternal behaviour are mediated in the central nervous system, demonstrated by the observation that icv infusion of prolactin or placental lactogen will induce maternal behaviour at doses that are without effect if administered peripherally $(59,60)$. Using localised injections into the MPOA, Bridges and colleagues have identified this region as a critical site for prolactin action to stimulate maternal behaviour (60). Prolactin receptors are expressed throughout this region (61-64), and levels are increased during lactation (64-66). Furthermore, prolactin induces phosphorylation of signal transducer and activator of transcription 5 (Stat5) in a large population of MPOA neurones, with neurones apparently more sensitive to prolactin during lactation $(67,68)$ (Fig. 1). Using the established steroid hormone regimen, it was found that bilateral MPOA infusions of the putative prolactin receptor antagonist S179D-prolactin delayed the onset of maternal behaviour in virgin rats by about 2 days (69). These findings provide support for an involvement of the prolactin receptor in the MPOA in the regulation of the onset of maternal care in the rat.

Interestingly, reproductive experience appears to provide a long-term change in the responsiveness to prolactin within the MPOA, as well as other central sites of prolactin action, i.e. arcuate, paraventricular nucleus (70). Basal expression of the long form of the prolactin receptor (70) as well as the response of this system to a prolactin challenge (71) increases as a result of reproductive experience. It seems possible that this enhanced response may contribute to the "maternal memory" that enables enhanced responsiveness to pups for an indefinite period after reproductive experience (72).

While mice show spontaneous maternal behaviour, this response is much enhanced in females after parturition. As in rats, earlier work implicated a role for prolactin acting in the hypothalamus to stimulate maternal behaviour and nest building in mice (73). There are high levels of prolactin receptor expression in the MPOA in mice (68), and increased responsiveness of this region to prolactin during lactation (67). The critical role of prolactin in maternal care was confirmed in the prolactin receptor knockout model, with a deficiency in pup-induced maternal care in both virgin and primiparous $\mathrm{Prlr}^{+/-}$mice, and an even more severe deficit in virgin Prlr $^{-/}$animals (74) (full knockouts are infertile, precluding study of maternal behaviour in parous animals). Interestingly, prolactin-deficient animals exhibit some maternal behaviour (75), possibly as a result of embryonic or neonatal exposure to prolactin/placental lactogen or actions of other ligands on the prolactin receptor (76). Prolactin actions on maternal behaviour in mice are not limited to the medial preoptic area.

This article is protected by copyright. All rights reserved. 
Prolactin-induced neurogenesis in the subventricular zone during early pregnancy (77) is also critical for the normal expression of maternal behaviour post partum $(78,79)$.

\section{Neuronal inputs contributing to the maintenance of maternal behaviours}

Oxytocin (Oxt) is secreted in the posterior pituitary from terminals of magnocellular neurones of the hypothalamic paraventricular and supraoptic nuclei (PVN and SON) in response to suckling as part of the milk ejection reflex (80). Although it is not likely that Oxt from the blood reaches preoptic neurones through the blood-brain barrier, Oxt is also released directly into the MPOA where it may have a neuromodulatory influence on MPOA neurones. It has been shown that preoptic injection of an Oxt receptor antagonist blocked the onset of maternal care (81) and mood adaptations in rats [in this issue, (82)]. Other reports have confirmed a role for Oxt in the initiation rather than the maintenance of maternal care (83-85), and in maternal-fetal signalling [in this issue, (86)]. Interestingly, oxytocin neurones express prolactin receptors (87) and are both acutely and chronically responsive to prolactin (88), suggesting the potential for interaction of these important lactation hormones. While it remains obscure whether magnocellular oxytocin neurones project to the MPOA to mediate the suckling input for maternal behaviours (89), the anatomical pathway from nipples to magnocellular oxytocin neurones is worth mentioning as it is the best-studied ascending pathway with specific maternal function. Lesion and microstimulation studies suggested that the milk-ejection reflex arc ascends through the lateral mesencephalic tegmentum and enters the zona incerta ventromedial to the medial geniculate body (90-92). Excitotoxic lesions of this area blocked the milk-ejection reflex (93) and c-fos expression was detected here in lactating mothers (94), suggesting relay of the pathway in this position. The same or a topographically very similar pathway mediates suckling-induced prolactin release $(95,96)$. Thus, the effect of suckling on maternal motivation and behaviour may also be mediated by a pathway reaching this area.

More details on this cell group were disclosed following the identification of a newly discovered neuropeptide in the region (97). Tuberoinfundibular peptide of 39 residues (Tip39) was purified as the ligand of the then orphan parathyroid hormone 2 receptor (Pth2r) (98). Tip39 is encoded by a single gene, which does not express any other known peptide (99). Tip39 is expressed in 2 thalamic and a pontine site and almost completely disappears from the brain by the end of pubertal development (100). It is, however, induced dramatically in lactating mothers in the posterior intralaminar complex (PIL) of the thalamus immediately ventromedial to the medial geniculate body (101) and the medial paralemniscal nucleus (102)

This article is protected by copyright. All rights reserved. 
but not the third site of its expression in the periventricular gray of the thalamus. The vast majority of neurones with induced Tip39 expression are labelled with Fos in response to suckling (101,102). The active role of Tip39 in mediating the suckling reflex was demonstrated by the near complete blockade of suckling-induced prolactin release by a Pth $2 \mathrm{r}$ antagonist (101). The projection of Tip39 neurones in the PIL to the arcuate nucleus but also to the preoptic area has been demonstrated using retrograde tracer injections and pathway transection studies (Fig. 2) (103-105). The projection of Tip39 fibres to the MPOA plays a role in maternal motivation because microinjection of a virus expressing a Pth2r antagonist into the MPOA blocked the formation of a conditioned place preference in lactating mothers, without affecting serum prolactin levels (105). Further, pups of mice lacking the Pth2r gene show reduced weight gain during lactation in an experiment where the pups of wild type as well as Pth2r knock-out mice were heterozygous (106). Cytoarchitectonic, chemoarchitectonic and Fos activational analysis of the PIL suggest that this area corresponds to the previously identified relay for suckling information during milk ejection $(101,105,107,108)$.

It is also conceivable that suckling information reaches the MPOA by other routes. A number of brain regions are activated following suckling, as determined by Fos expression (109). For example, suckling information may reach the MPOA via the activation of argininvasopressin (Avp) neurones located in the magnocellular subdivision of the PVN. Indeed, Avp gene expression is increased in PVN neurones during suckling (110,111). Avp is released in the MPOA during maternal behaviour (112). Furthermore, up-regulation of Avp V1a receptors within the MPOA of lactating rats improved maternal care, while local blockade of V1a receptor expression and its direct pharmacological inhibition impaired it $(81,113)$.

Stimuli other than suckling may also reach the MPOA to contribute to the maintenance of maternal responsiveness. Analysis of pup movement showed that after reaching a supine posture, the pup crawls to a nipple by performing "stepping" movements on the mother's ventral body surface (114). Thus, in the above listed experiments, somatosensory stimulation of the ventral body surface by pups may also contribute to evoking the preoptic responses (115). In addition, a specific auditory input from the pups, ultrasonic vocalization, can enhance maternal responsiveness (116) in a synergistic way with odour inputs (117). Since ultrasonic vocalization may evoke Prl release, a hormonal mediation is possible (118). However, neurones activated by high intensity acoustic input in the area corresponding to the PIL (119) are candidates to convey information to the MPOA (105) suggesting the existence

This article is protected by copyright. All rights reserved. 
of a neuronal pathway, by which ultrasonic vocalization can reach the MPOA. In contrast, visual stimuli have not been experimentally supported to significantly induce maternal behaviours. Rather, the olfactory inputs have been emphasized in the regulation of maternal responsiveness in rodents (1). The role of olfactory input has been shown to change during the maternal sensitization process in rats (120). The valence of pup odours seems to change during the transition to motherhood (121). Initially aversive pup odours become attractive to rat dams and therefore, might play a role in the maintenance of maternal responsiveness $(37,122)$. Odour information reaches the MPOA via the medial and cortical amygdaloid nuclei (123).

\section{Alterations of neuronal activity and gene expression in the maternal preoptic area}

The electrophysiological activity of MPOA neurones has not been investigated in relation to maternal behaviour. Still, their activation is likely as brain activity is elevated in the MPOA based on c-fos, 2-deoxyglucose (124) and fMRI techniques (125). The most detailed studies allowing cellular resolution were performed using the c-fos method $(109,126-128)$. There is a strong basal c-fos activity in the preoptic area, which is reduced when the litter is taken away. Therefore, a typical experiment examines the Fos immunoreactivity pattern after the litter is returned following previous separation. Using this technique, the activity of neurones was demonstrated in a $\mathrm{V}$-shaped distribution pattern in coronal sections with the $3^{\text {rd }}$ ventricle being in the middle. Ventrally, many neurones are labelled in the medial preoptic nucleus. A high density of neurones are also Fos-positive dorsolateral to this area and also further dorsolaterally in the ventral subdivision of the bed nucleus of the stria terminalis up to the anterior commissure. Limited information is available on the characteristics of labelled neurones but they appear to represent a diverse group of cells. About half of the activated neurones are GABA-ergic (129) and many of these are projection neurones (34). The distribution of estrogen receptor alpha (Esr1) expressing neurones overlaps with c-fos expressing cells. About $10 \%$ of Esr1-positive cells are activated by pup exposure, which means that about $40 \%$ of c-fos-expressing neurones contain Esr1 (130). The activation of these neurones can occur in the absence of pregnancy hormone stimulation, for example in ovariectomized, behaviourally-sensitized rats (131). Some neuropeptide markers also coexpress with Fos-positive neurones. Amylin neurones have a similar distribution as the activated cells and almost all are Fos-positive but still represent only a subset of Fos-positive neurones (132). Similarly, a portion of activated neurones contained galanin, neurotensin, and/or tachykinin 2 (51). Furthermore, about half of the activated neurones contained Avp

This article is protected by copyright. All rights reserved. 
receptor but almost no co-expression was found for the Oxt receptor (51). The specific functions of these cell groups remain to be disclosed in future studies.

\section{Gene expressional changes in the preoptic area of mothers}

The expression of c-fos is an indicator of neuronal activity but is also a transcription factor with altered expression level in the MPOA. Another transcription factor, Fos B, is expressed in the MPOA in a similar pattern to c-fos-positive neurones in response to pup exposure (131). Fos B expression appears with some delay but lasts longer than c-fos (133). Although the number of Fos B-immunoreactive neurones is 3-4 times lower than the number of c-fos expressing neurones, co-expression is likely (134). Interestingly, mice lacking Fos B were selectively deficient in maternal responsiveness suggesting its role in this process (135). Another transcription factor, NGF1-B, which, similar to Fos and Fos B, can also be regulated by the extracellular signal regulated kinase (Erk), as well as 2 downstream regulatory elements of Fos B, Rad and Spry1 were also found to be induced in maternal mice suggesting their maternal functions and the role of Erk in the process (136). Furthermore, a recent microarray study suggested that a number of additional transcription factors and co-factors have altered expression levels in the preoptic area of mothers (137).

Neuropeptide gene expression is also increased in the MPOA of mothers. These neuropeptides may play a role in the execution of maternal responsiveness as neuromodulators. The expression level of Oxt is elevated in the anterior subcommissural nucleus in mothers (138), which may be related to the control of maternal behaviours (139). However, potential relationship and similarities between Oxt neurones in the anterior subcommissural and paraventricular / supraoptic nuclei remain to be established.

The gene expression of melanin-concentrating hormone (Mch) was induced in the medial preoptic nucleus of mother rats (140). This cell group is clearly different from Mch cells in the lateral hypothalamic area whose expression level is actually reduced in mothers (141). Interestingly, Mch levels in the preoptic area increased with postnatal days. Some elevation appeared at 5 days postpartum but Mch mRNA as well as peptide levels were maximal (over 10 times increase) at postpartum day 19 (142). It is possible that Mch expression is related to the physiological starving characteristic in this late period of nursing the growing pups.

Another recently discovered maternally induced neuropeptide is amylin (or islet amyloid polypeptide - Iapp), which is exclusively expressed in the MPOA of rat dams (143).

This article is protected by copyright. All rights reserved. 
Previously, amylin was only found in the pancreas (144). A microarray study comparing gene expression between mother and pup-deprived mother rats identified amylin as the gene with the largest increase in its expression level (over 25 times) in the maternal preoptic area (143). The distribution of amylin neurones is similar to that of maternally active neurones (145). Indeed, 90\% of amylin neurones are labelled with Fos in response to pup exposure, but only $27 \%$ of Fos-positive neurones contain amylin in the MPOA (132). A role of amylin in maternal motivation and behaviour, rather than in feeding, was suggested by its immediate elevation after parturition and its induction in maternally sensitized control female rats (132).

Neurones containing the neuropeptide neurotensin are distributed in all parts of the MPOA and about one third of them are activated by pup exposure (51). A small (about 1.5 times) but significant increase was found in the mRNA level of neurotensin and one of its receptors (neurotensin receptor 3 - Sort1) in the MPOA, but not in some other hypothalamic regions and the amygdala (146). It has also been demonstrated that endogenous neurotensin signaling is altered in the postpartum period (147) suggesting a role of neurotensin in maternal behaviours.

In MPOA, corticotropin releasing hormone (Crh) expression was higher in lactating females compared with virgin and pregnant rats and did not increase further in response to stress (148). The available information on the function of elevated Crh in the maternal MPOA is limited. A study showed that Crh actually inhibited maternal behavior and induced pupkilling (149).It remains to be elucidated whether the reported alteration in Crh expression is related to maternal behaviours or the reduced anxiety and stress response of lactating dams.

Apart from neuropeptides, some hormone receptors have elevated levels in the maternal MPOA, too. Prolactin receptor (Prlr) levels were elevated in the ventromedial and ventrolateral preoptic nuclei in the postpartum period (150). Pharmacological manipulation of prolactin levels suggested that this increase is the direct result of neuronal activation (151). Oxt receptor expression was also increased in the MPOA during parturition, but returned to control level in the postpartum period $(112,152)$. In contrast, a recent study suggested that Oxt receptor expression remains elevated in the postpartum period (137). AVP receptor expression is also increased in lactating rats $(84,113)$.

We have limited information on the changes in gene expression level of other proteins in mothers. Systems biological approaches have addressed this question only a few times. In a microarray study, gene expression of 11904 genes was compared between lactating mothers

This article is protected by copyright. All rights reserved. 
and virgin female mice in the hypothalamus (including the MPOA) and nucleus accumbens (153). Several genes belonging to neuropeptides, growth factors, receptors, elements of signal transduction pathways, neuroimmune factors, and mitochondrial genes were induced in mothers (153). Unfortunately, qRT-PCR verification was reported for only a few genes, including Cited2 and Plk2. Cited2 is a Cbp/p300-interacting transactivator required during development (154) but still does not have an established neural function. Plk2 is a polo-like kinase that has been recently suggested to silence synuclein at the synapse (155).

Another microarray study investigated gene expression exclusively in the MPOA of maternal lactating female rats compared with mother rats that were deprived of their pups immediately after delivery. This study identified the maternal neuropeptide amylin (as described above) but other genes were not further analysed (143). The dorsal part of MPOA was examined in another microarray study, which reported the transcription factors: c-fos, Fos B, Ngf1-B, Rad, and Spry1 induced in both parentally behaving males and females (136). A recent microarray study, which compared gene expression of 35557 targets in the medial preoptic area between mother mice and control females, found 734 annotated genes, whose expression changed significantly in the maternal preoptic area (137). Subsequent modular single set enrichment procedure proved that genes implicated in disorders with social deficits were overrepresented in the altered gene list (137). Among the 13 genes tested with qRTPCR, 7 were validated as significantly altered. B cell leukemia/lymphoma 2 (Bcl2), glutamate-ammonia ligase (Glul), Oxtr, and suppressor of cytokine signalling (Socs2) were upregulated in mothers, while the level of angitensin 1 converting enzyme (Ace), GABA A receptor, subunit epsilon (Gabre), and nitric oxide sythase 1 were significantly decreased (137). Another recent microarray study comparing mother and maternally behaving rats with non-maternal females found that dopamine receptor D4 (Drd4), dopamine transporter (Dat), glucocorticoid-related gene Cypx1b1a, opioid receptor, mu 1 (Oprm1), and 5hydroxytryptamine (serotonin) receptor $2 \mathrm{~A}$ are genes with altered maternal expression (156).

The distribution, temporal course of induction, and function, of the genes identified by the above discussed microarray studies are not known yet. Thus, further studies are needed to identify the role of maternally expressed genes in the MPOA and its subdivisions. It is equally important to establish the precise temporal patterns of the gene expression of maternally involved genes. For some genes, the expression changes may be related to continuous neuronal or hormonal input and wane after weaning of the pups. However, maternal

This article is protected by copyright. All rights reserved. 
responsiveness remains elevated for a long period of time following maternal experience, which may be accompanied with long-term gene expression changes.

\section{Epigenetic mechanisms that control the expression of genes involved in maternal responsiveness}

The transition into motherhood is associated with gene expression changes within the MPOA, described above, which regulate maternal responsiveness. Furthermore, these alterations in gene expression within the MPOA likely support the maintenance of maternal care because damage to the MPOA, even when that damage occurs after the experience of rearing a litter, results in poor maternal responsiveness $(51,157)$. A critical question is how the alterations in neuronal phenotype described above support the long-lasting maintenance of maternal responsiveness to infants (158-162).

One possibility is that chromatin modifications regulate genetic networks involved in the reorganization of the MPOA during initial mother-infant interactions. Chromatin is the complex of DNA compactly coiled around histone proteins. Numerous post-translational modifications to histones such as acetylation and methylation can occur, and DNA itself can also be modified by methylation. These "epigenetic marks" exist above the level of the genome to control gene expression (163). The placement of epigenetic marks on the epigenome is regulated by the enzymatic activity of proteins. Histone acetyltransferases (HATs) add acetyl groups to proteins, histone deacetyltransferases (HDACs) remove them, and DNA methyltransferases (DNMTs) add methyl groups to the cytosine residues of DNA. Post-translational modifications to histone protein tails regulate gene transcription by remodelling the structure of chromatin (the strength of association between histones and DNA) and/or altering transcription factor binding. Histone acetylation neutralizes the positive charge of histone proteins, "loosening" their association with negatively charged DNA, and increasing transcription factor access to DNA sequences. DNA itself is also a target for remodelling; cytosine methylation tightens the chromatin structure and can result in recruitment of DNA methylated binding proteins that repress gene transcription. As chromatin modifications become an increasing area of research, it is clear that generalizations about the consequences of chromatin remodelling on transcriptional activity are insufficient. For example, it is tempting to link specific modifications with on/off states of gene transcription, but this view is not always supported by data [for a thoughtful discussion see (164)]. Similarly, classification of acetylation as dynamic and reversible, but methylation of histones or DNA as stable and permanent, is not accurate $(165,166)$.

This article is protected by copyright. All rights reserved. 
If dynamic regulation of acetylation and methylation occur in response to cell signalling pathways $(165,166)$, is chromatin remodelling a final common pathway through which different factors (hormonal, experiential) produce long-term changes in the way MPOA neurones respond to infant stimuli (Fig. 3)? One possibility is that in the absence of pregnancy hormones, repeated sensory inputs from pups ultimately stimulate the same molecular pathways [for review see (167)]. Intracellular signalling cascades affect histone acetylation by activating HAT enzymes, such as Creb binding protein (Crebbp). CBP-mediated histone acetylation is a logical candidate mechanism because Crebbp can be turned on by hormonal factors (Crebbp is a coactivator at estrogen receptors) as well as experiential factors (neural activity during mother-infant interaction), and regulates gene expression in MPOA neurones by remodelling chromatin $(165,166,168)$. Thus, it is certainly possible that the mechanism through which the surge of estradiol just before birth activates maternal behaviour involves recruitment of HATs. In support of this idea, estradiol and dopamine D1 receptor stimulation of the MPOA produce strikingly similar effects on maternal responses $(169,170)$. Activation of Creb and Erk signalling pathways support maternal responsiveness in both postpartum and virgin female mice and increases in Crebbp gene expression are seen in both postpartum and virgin mice that show maternal responsiveness $(136,153,171-173)$.

If chromatin remodelling is a final common pathway through which hormones and experience activate maternal responsiveness, is it also involved in the consolidation of maternal experience and/or the maintenance of maternal memory? Consistent with the idea that maternal experience is consolidated, as in other forms of learning; maternal learning requires Creb-mediated gene transcription (173). Recent evidence supports the idea that the consolidation of maternal experience may involve Crebbp-mediated histone acetylation $(171,174)$. In the absence of pregnancy hormones, HDAC inhibition potentiated sub-threshold amounts of maternal experience, such that maternal motivation was not statistically different than postpartum females. Maternal motivation was measured by the latency to retrieve scattered pups from the far ends of a novel T-maze back to the nest. When mice were retested 1-month after maternal experience and/or HDACi treatment, pup retrieval responses were consistent [manuscript under review, also see (29)]. Importantly, the fact that experience-dependent changes in maternal responses appear to be regulated by Crebbp-HAT activity, affords the opportunity to identify chromatin modifications that initiate and stabilize transcriptional activities required for maternal memory. This line of research may help clarify

This article is protected by copyright. All rights reserved. 
how initial neuronal inputs (hormonal and experiential) come to leave lasting effects on gene expression.

Considering that histone acetylation is a transcriptional regulatory mechanism that allows for increased transcription of particular genes, it is not surprising that administration of an HDACi not only affects behavioural responses toward pups but also potentiates the expression of genes associated with maternal care in the MPOA. For example, maternal experience increases the expression of some of the genes identified as relevant for maternal behaviour: estrogen receptor beta (Esr2), oxytocin (Oxt), oxytocin receptor (Oxtr), vasopressin (Avp), and vasopressin receptor (Avp1a). Undoubtedly, other genes are also involved in maternal behaviour, such as those described above including Tip39, as well as novel targets that have yet to be discovered. However, experimental evidence of epigenetic alterations during maternal learning is currently available only for a subset of genes. For example, epigenetic regulation of Esr1 expression plays an important role in the development of maternal behaviour (175), but Esr1 expression does not seem to be modified during maternal experience consolidation in virgin mice (171). Administration of an HDACi during sub-threshold experience increases the expression of Crebbp, Esr2, and Oxt (171). Importantly, these gene expression changes are tightly linked to maternal responses on the Tmaze, suggesting their up-regulation coincides with maternal experience consolidation (Fig. 4). Furthermore, Crebbp is recruited to Esr2 and Oxt gene promoters, suggesting that it may be involved in transcriptional regulation of these genes [manuscript under review].

Finally, although the idea that dynamic regulation of the epigenome might support the long-lasting changes in MPOA neurones that sustain maternal motivation is new, a growing body of research has linked dynamically driven epigenetic changes to mechanisms underlying the consolidation of long-term memories [in this issue, $(176,177)]$. In the hippocampus and amygdala, increased histone acetylation (178-182) and increased Crebbp have been linked to memory formation $(183,184)$. Further, administration of HDAC inhibitors, which allow for increased acetylation, enhance memory formation (178-180,182,183,185-187), and this effect depends on the HAT activity of Crebbp (180). More recently, a role for chromatin modifications in estradiol facilitation of learning and memory has been elucidated (188-190). Thus, the data linking histone acetylation to the consolidation of maternal experience and regulation of gene expression in the MPOA are a first step toward understanding epigenetic involvement in maternal experience. Future work is needed to identify the epigenetic signature that underlies plasticity in the MPOA.

This article is protected by copyright. All rights reserved. 


\section{Conclusions}

Hormonal changes during pregnancy initiate complex behavioural changes to promote maternal care of the offspring after birth. These behaviours are reinforced and extended by sensory neural inputs, initiated either by suckling, or by the sight, smell and sounds of dependent offspring. Both mechanisms converge on the MPOA, promoting changes in gene expression to maintain maternal responses. Essentially these changes lead to the maternal adaptation of the brain. Once established, the memory of this maternal experience is permanently maintained through processes that are likely to involve epigenetic changes.

\section{Acknowledgements}

Grant support was provided by the Bolyai János Award of the Hungarian Academy of Sciences, an OTKA K100319 research grant of the Hungarian Scientific Research Fund, and the KTIA NAP_13-2-2014 Program for AD. DRG was supported by the Health Research Council of New Zealand, and the Royal Society of New Zealand Marsden Fund.

\section{References}

1 Numan M, Insel TR (2003) The Neurobiology of Parental Behavior. New York: Springer. 2003.

2 Numan M, Fleming AS, Levy F Maternal Behavior. In: Neill JD, editor. Knobil and Neill's Physiology of Reproduction. Oxford: Academic Press. 2006: pp. 1729-2058.

3 Moses-Kolko EL, Horner MS, Phillips ML, Hipwell AE, Swain JE. In search of neural endophenotypes of postpartum psychophysioloy and discrupted maternal caregiving. $J$ Neuroendocrinol 2014: In press.

4 Olazabal DE, Pereira M, Agrati D, Ferreira A, Fleming AS, Gonzalez-Mariscal G, Levy F, Lucion AB, Morrell JI, Numan M, Uriarte N. Flexibility and adaptation of the neural substrate that supports maternal behavior in mammals. Neurosci Biobehav Rev 2013; 37: $1875-1892$.

5 Olazabal DE, Pereira M, Agrati D, Ferreira A, Fleming AS, Gonzalez-Mariscal G, Levy F, Lucion AB, Morrell JI, Numan M, Uriarte N. New theoretical and experimental approaches on maternal motivation in mammals. Neurosci Biobehav Rev 2013; 37: 1860-1874.

6 Siegel HI. Hormonal basis of maternal behavior in the rat. Ann N Y Acad Sci 1986; 474: 202-215.

This article is protected by copyright. All rights reserved. 
7 Stern JM, Mackinnon DA. Postpartum, hormonal, and nonhormonal induction of maternal behavior in rats: effects on T-maze retrieval of pups. Horm Behav 1976; 7: 305-316.

8 Lee A, Clancy S, Fleming AS. Mother rats bar-press for pups: effects of lesions of the mpoa and limbic sites on maternal behavior and operant responding for pup-reinforcement. Behav Brain Res 2000; 108: 215-231.

9 Gandelman R, Zarrow, M.X., Denenberg, V.H. Maternal Behavior: Differences between mother and virgin mice as a function of testing procedure. Developmental Psychobiology 1973; 3: 207-214.

10 Fleming AS, Korsmit, M., Deller, M. Rat pups are potent reinforcers to the maternal animal: Effects of experience, parity, hormones, and dopamine function. Psychobiology 1994; 22: 44-53.

11 Bridges R, Zarrow MX, Gandelman R, Denenberg VH. Differences in maternal responsiveness between lactating and sensitized rats. Dev Psychobiol 1972; 5: 123 127.

12 Siegel HI, Greenwald GS. Prepartum onset of maternal behavior in hamsters and the effects of estrogen and progesterone. Horm Behav 1975; 6: 237-245.

13 Siegel HI, Rosenblatt JS. Progesterone inhibition of estrogen-induced maternal behavior in hysterectomized-ovariectomized virgin rats. Horm Behav 1975; 6: 223-230.

14 Siegel HI, Rosenblatt JS. Hormonal basis of hysterectomy-induced maternal behavior during pregnancy in the rat. Horm Behav 1975; 6: 211-222.

15 Rosenblatt JS, Siegel HI. Hysterectomy-induced maternal behavior during pregnancy in the rat. J Comp Physiol Psychol 1975; 89: 685-700.

16 Siegel HI, Rosenblatt JS. Estrogen-induced maternal behavior in hysterectomizedoveriectomized virgin rats. Physiol Behav 1975; 14: 465-471.

17 Terkel J, Rosenblatt JS. Maternal behavior induced by maternal blood plasma injected into virgin rats. J Comp Physiol Psychol 1968; 65: 479-482.

18 Moltz H, Lubin M, Leon M, Numan M. Hormonal induction of maternal behavior in the ovariectomized nulliparous rat. Physiol Behav 1970; 5: 1373-1377.

19 Bridges RS. A quantitative analysis of the roles of dosage, sequence, and duration of estradiol and progesterone exposure in the regulation of maternal behavior in the rat. Endocrinology 1984; 114: 930-940.

20 Orpen BG, Fleming AS. Experience with pups sustains maternal responding in postpartum rats. Physiol Behav 1987; 40: 47-54.

This article is protected by copyright. All rights reserved. 
21 Bridges RS. Retention of rapid onset of maternal behavior during pregnancy in primiparous rats. Behav Biol 1978; 24: 113-117.

22 Bridges RS. Long-term effects of pregnancy and parturition upon maternal responsiveness in the rat. Physiol Behav 1975; 14: 245-249.

23 Rosenblatt JS, Mayer AD, Giordano AL. Hormonal basis during pregnancy for the onset of maternal behavior in the rat. Psychoneuroendocrinology 1988; 13: 29-46.

24 Stern JM Maternal Behavior: Sensory, Hormonal and Neural Determinants. In: Brush FR, Levine AS, editors. Psychoendocrinology. San Diego: Academic Press. 1989: pp. 103226.

25 Svare BB. Anabolic steroids and behavior: a preclinical research prospectus. NIDA Res Monogr 1990; 102: 224-241.

26 Braun K, Champagne FA. Paternal influences on offspring development: behavioural and epigenetic pathways. J Neuroendocrinol 2014: In press.

27 Saltzman W, Ziegler TE. Functional significance of hormonal changes in mammalian fathers. J Neuroendocrinol 2014: In press.

28 Rosenblatt JS. Nonhormonal basis of maternal behavior in the rat. Science 1967; 156: 1512-1514.

29 Stolzenberg DS, Rissman EF. Oestrogen-independent, experience-induced maternal behaviour in female mice. J Neuroendocrinol 2011.

30 Koch M, Ehret G. Estradiol and parental experience, but not prolactin are necessary for ultrasound recognition and pup-retrieving in the mouse. Physiol Behav 1989; 45: 771776.

31 Ehret GK, M., Haack, B., Markl, H. Sex and parental experience determine the onset of an instinctive behavior in mice. Naturwissenschaften 1989; 74: 47.

32 Bridges RS. Parturition: Its role in the long term retention of maternal behavior in the rat

Physiology and Behavior 1977; 18: 487-490.

33 Galea LAM, Leuner B, Slattery DA. Hippocampal plasticity during the peripartum period: influence of sex steroids, stress and ageing. J Neuroendocrinol 2014: In press.

34 Numan M, Numan MJ. Projection sites of medial preoptic area and ventral bed nucleus of the stria terminalis neurons that express Fos during maternal behavior in female rats. $J$ Neuroendocrinol 1997; 9: 369-384.

35 Numan M, Sheehan TP. Neuroanatomical circuitry for mammalian maternal behavior. Ann N Y Acad Sci 1997; 807: 101-125.

This article is protected by copyright. All rights reserved. 
36 Numan M, Numan MJ. Importance of pup-related sensory inputs and maternal performance for the expression of Fos-like immunoreactivity in the preoptic area and ventral bed nucleus of the stria terminalis of postpartum rats. Behav Neurosci 1995; 109: 135-149.

37 Gonzalez-Mariscal G, Poindron P Parental care in mammals: immediate internal and sensory factors in control. In: Pfaff D, Arnold A, Etgen A, Fahrbach S, Rubin R, editors. Hormones, Brain and Behavior. San Diego: Academic Press. 2002: pp. 215298.

38 Febo M, Stolberg TL, Numan M, Bridges RS, Kulkarni P, Ferris CF. Nursing stimulation is more than tactile sensation: It is a multisensory experience. Horm Behav 2008; 54: 330-339.

39 Gurdijan ES. The diencephalon of the albino rat. J Comp Neurol 1927; 43: 1-114.

40 Gorski RA. Sexual dimorphisms of the brain. J Anim Sci 1985; 61 Suppl 3: 38-61.

41 Dodson RE, Gorski RA. Testosterone propionate administration prevents the loss of neurons within the central part of the medial preoptic nucleus. J Neurobiol 1993; 24 : 80-88.

42 Ju G, Swanson LW, Simerly RB. Studies on the cellular architecture of the bed nuclei of the stria terminalis in the rat: II. Chemoarchitecture. J Comp Neurol 1989; 280: 603621.

43 Paxinos G, Watson C (2007) The rat brain in stereotaxic coordinates. San Diego: Academic Press. 2007.

44 Jirikowski GF, Caldwell JD, Pedersen CA, Stumpf WE. Estradiol influences oxytocinimmunoreactive brain systems. Neuroscience 1988; 25: 237-248.

45 Sofroniew MV. Vasopressin- and neurophysin-immunoreactive neurons in the septal region, medial amygdala and locus coeruleus in colchicine-treated rats. Neuroscience 1985; 15: 347-358.

46 Numan M. Medial preoptic area and maternal behavior in the female rat. J Comp Physiol Psychol 1974; 87: 746-759.

47 Numan M, Corodimas KP, Numan MJ, Factor EM, Piers WD. Axon-sparing lesions of the preoptic region and substantia innominata disrupt maternal behavior in rats. Behav Neurosci 1988; 102: 381-396.

48 Pereira M, Morrell JI. The changing role of the medial preoptic area in the regulation of maternal behavior across the postpartum period: facilitation followed by inhibition. Behav Brain Res 2009; 205: 238-248.

This article is protected by copyright. All rights reserved. 
49 Arrati PG, Carmona C, Dominguez G, Beyer C, Rosenblatt JS. GABA receptor agonists in the medial preoptic area and maternal behavior in lactating rats. Physiol Behav 2006; 87: 51-65.

50 Jacobson CD, Terkel J, Gorski RA, Sawyer CH. Effects of small medial preoptic area lesions on maternal behavior: retrieving and nest building in the rat. Brain Res 1980; 194: 471-478.

51 Tsuneoka Y, Maruyama T, Yoshida S, Nishimori K, Kato T, Numan M, Kuroda KO. Functional, anatomical, and neurochemical differentiation of medial preoptic area subregions in relation to maternal behavior in the mouse. J Comp Neurol 2013; 521: 1633-1663.

52 Morgan HD, Watchus JA, Fleming AS. The effects of electrical stimulation of the medial preoptic area and the medial amygdala on maternal responsiveness in female rats. Ann N Y Acad Sci 1997; 807: 602-605.

53 Lehrman DS, Brody P. Does prolactin induce incubation behavior in the ring dove? $J$ Endocrinol 1961; 22: 269-275.

54 Zarrow MX, Farooq A, Denenberg VH, Sawin PB, Ross S. Maternal Behaviour in the Rabbit: Endocrine Control of Maternal Nest Building. J Reprod Fertil 1963; 6: 375383.

55 Zarrow MX, Sawin PB, Ross S, Denenberg VH, Crary D, Wilson ED, Farooq A. Maternal behaviour in the rabbit: evidence for an endocrine basis of maternalnest building and additional data on maternal-nest building in the Dutch-belted race. $J$ Reprod Fertil 1961; 2: 152-162.

56 Bluem V, Fiedler K. Hormonal Control Reproductive Behavior in Some Cichlid Fish. Gen Comp Endocrinol 1965; 56: 186-196.

57 Bridges RS, DiBiase R, Loundes DD, Doherty PC. Prolactin stimulation of maternal behavior in female rats. Science 1985; 227: 782-784.

58 Bridges RS, Ronsheim PM. Prolactin (PRL) regulation of maternal behavior in rats: bromocriptine treatment delays and PRL promotes the rapid onset of behavior. Endocrinology 1990; 126: 837-848.

59 Bridges RS, Robertson MC, Shiu RPC, Friesen HG, Stuer AM, Mann PE. Endocrine communication between conceptus and mother: Placental lactogen stimulation of maternal behavior. Neuroendocrinology 1996; 64: 57-64.

60 Bridges RS, Numan M, Ronsheim PM, Mann PE, Lupini CE. Central prolactin infusions stimulate maternal behavior in steroid-treated, nulliparous female rats. Proceedings of

This article is protected by copyright. All rights reserved. 
the National Academy of Sciences of the United States of America 1990; 87: 80038007.

61 Bakowska JC, Morrell JI. Atlas of the neurons that express mRNA for the long form of the prolactin receptor in the forebrain of the female rat. Journal of Comparative Neurology 1997; 386: 161-177.

62 Bakowska JC, Morrell JI. The distribution of mRNA for the short form of the prolactin receptor in the forebrain of the female rat. Brain Res Mol Brain Res 2003; 116: 50-58.

$63 \mathrm{Pi}$ XJ, Grattan DR. Distribution of prolactin receptor immunoreactivity in the brain of estrogen-treated, ovariectomized rats. Journal of Comparative Neurology 1998; 394: 462-474.

64 Pi XJ, Grattan DR. Increased prolactin receptor immunoreactivity in the hypothalamus of lactating rats. J Neuroendocrinol 1999; 11: 693-705.

65 Mann PE, Bridges RS. Prolactin receptor gene expression in the forebrain of pregnant and lactating rats. Brain Res Mol Brain Res 2002; 105: 136-145.

66 Bridges RS, Hays LE. Steroid-induced alterations in mRNA expression of the long form of the prolactin receptor in the medial preoptic area of female rats: Effects of exposure to a pregnancy-like regimen of progesterone and estradiol. Brain Res Mol Brain Res 2005; 140: 10-16.

67 Brown RS, Herbison AE, Grattan DR. Differential changes in responses of hypothalamic and brainstem neuronal populations to prolactin during lactation in the mouse. Biology of Reproduction 2011; 84: 826-836.

68 Brown RS, Kokay IC, Herbison AE, Grattan DR. Distribution of prolactin-responsive neurons in the mouse forebrain. J Comp Neurol 2010; 518: 92-102.

69 Bridges RS, Rigero BA, Byrnes EM, Yang LL, Walker AM. Central infusions of the recombinant human prolactin receptor antagonist, S179D-PRL, delay the onset of maternal behavior in steroid-primed, nulliparous female rats. Endocrinology 2001; 142: 730-739.

70 Anderson GM, Grattan DR, van den Ancker W, Bridges RS. Reproductive experience increases prolactin responsiveness in the medial preoptic area and arcuate nucleus of female rats. Endocrinology 2006; 147: 4688-4694.

71 Sjoeholm A, Bridges RS, Grattan DR, Anderson GM. Region-, neuron-, and signaling pathway-specific increases in prolactin responsiveness in reproductively experienced female rats. Endocrinology 2011; 152: 1979-1988.

This article is protected by copyright. All rights reserved. 
72 Scanlan VF, Byrnes EM, Bridges RS. Reproductive experience and activation of maternal memory. Behav Neurosci 2006; 120: 676-686.

73 Voci VE, Carlson NR. Enhancement of maternal behavior and nest building following systemic and diencephalic administration of prolactin and progesterone in the mouse. J Comp Physiol Psychol 1973; 83: 388-393.

74 Lucas BK, Ormandy CJ, Binart N, Bridges RS, Kelly PA. Null mutation of the prolactin receptor gene produces a defect in maternal behavior. Endocrinology 1998; 139: 41024107.

75 Horseman ND, Zhao WZ, Montecinorodriguez E, Tanaka M, Nakashima K, Engle SJ, Smith F, Markoff E, Dorshkind K. Defective mammopoiesis, but normal hematopoiesis, in mice with a targeted disruption of the prolactin gene. EMBO Journal 1997; 16: 6926-6935.

76 Melo AI, Perez-Ledezma M, Clapp C, Arnold E, Rivera JC, Fleming AS. Effects of prolactin deficiency during the early postnatal period on the development of maternal behavior in female rats: mother's milk makes the difference. Horm Behav 2009; 56: 281-291.

77 Shingo T, Gregg C, Enwere E, Fujikawa H, Hassam R, Geary C, Cross JC, Weiss S. Pregnancy-stimulated neurogenesis in the adult female forebrain mediated by prolactin. Science 2003; 299: 117-120.

78 Larsen CM, Grattan DR. Prolactin-induced mitogenesis in the subventricular zone of the maternal brain during early pregnancy is essential for normal postpartum behavioral responses in the mother. Endocrinology 2010; 151: 3805-3814.

79 Larsen CM, Grattan DR. Prolactin, neurogenesis, and maternal behaviors. Brain Behav Immun 2012; 26: 201-209.

80 Burbach JPH, Young LJ, Russell JA Oxytocin: Synthesis, Secretion, and Reproductive Functions. In: Neill JD, editor. Knobil and Neill's Physiology of Reproduction. Oxford: Academic Press. 2006: pp.

81 Pedersen CA, Caldwell JD, Walker C, Ayers G, Mason GA. Oxytocin activates the postpartum onset of rat maternal behavior in the ventral tegmental and medial preoptic areas. Behav Neurosci 1994; 108: 1163-1171.

82 Lonstein JS, Maguire J, Meinlschmidt G, Neumann ID. Emotion and mood adaptations in the peripartum female: complementary contributions of gamma-aminobutyric acid and oxytocin. J Neuroendocrinol 2014: In press.

This article is protected by copyright. All rights reserved. 
83 Leng G, Meddle SL, Douglas AJ. Oxytocin and the maternal brain. Curr Opin Pharmacol 2008; 8: 731-734.

84 Bosch OJ, Neumann ID. Both oxytocin and vasopressin are mediators of maternal care and aggression in rodents: from central release to sites of action. Horm Behav 2012; 61: 293-303.

85 Lin SH, Kiyohara T, Sun B. Maternal behavior: activation of the central oxytocin receptor system in parturient rats? Neuroreport 2003; 14: 1439-1444.

86 Kenkel WM, Yee JR, Carter CS. Is oxytocin a maternal-fetal signaling molecule at birth? Implications for development. J Neuroendocrinol 2014: In press.

87 Kokay IC, Bull PM, Davis RL, Ludwig M, Grattan DR. Expression of the long form of the prolactin receptor in magnocellular oxytocin neurons is associated with specific prolactin regulation of oxytocin neurons. Am J Physiol Regul Integr Comp Physiol 2006; 290: R1216-1225.

88 Sapsford TJ, Kokay IC, Ostberg L, Bridges RS, Grattan DR. Differential sensitivity of specific neuronal populations of the rat hypothalamus to prolactin action. J Comp Neurol 2012; 520: 1062-1077.

89 Ross HE, Cole CD, Smith Y, Neumann ID, Landgraf R, Murphy AZ, Young LJ. Characterization of the oxytocin system regulating affiliative behavior in female prairie voles. Neuroscience 2009; 162: 892-903.

90 Juss TS, Wakerley JB. Mesencephalic areas controlling pulsatile oxytocin release in the suckled rat. J Endocrinol 1981; 91: 233-244.

91 Dubois-Dauphin M, Armstrong WE, Tribollet E, Dreifuss JJ. Somatosensory systems and the milk-ejection reflex in the rat. II. The effects of lesions in the ventroposterior thalamic complex, dorsal columns and lateral cervical nucleus-dorsolateral funiculus. Neuroscience 1985; 15: 1131-1140.

92 Tindal JS, Knaggs GS. Determination of the detailed hypothalamic route of the milkejection reflex in the guinea-pig. $J$ Endocrinol 1971; 50: 135-152.

93 Hansen S, Kohler C. The importance of the peripeduncular nucleus in the neuroendocrine control of sexual behavior and milk ejection in the rat. Neuroendocrinology 1984; 39: 563-572.

94 Lin SH, Miyata S, Matsunaga W, Kawarabayashi T, Nakashima T, Kiyohara T. Metabolic mapping of the brain in pregnant, parturient and lactating rats using fos immunohistochemistry. Brain Res 1998; 787: 226-236.

This article is protected by copyright. All rights reserved. 
95 Tindal JS, Knaggs GS. Pathways in the forebrain of the rat concerned with the release of prolactin. Brain Res 1977; 119: 211-221.

96 Wakerley JB, O'Neill DS, ter Haar MB. Relationship between the suckling-induced release of oxytocin and prolactin in the urethane-anaesthetized lactating rat. $J$ Endocrinol 1978; 76: 493-500.

97 Dobolyi A, Palkovits M, Usdin TB. Expression and distribution of tuberoinfundibular peptide of 39 residues in the rat central nervous system. J Comp Neurol 2003; 455: 547-566.

98 Usdin TB, Hoare SR, Wang T, Mezey E, Kowalak JA. TIP39: a new neuropeptide and PTH2-receptor agonist from hypothalamus. Nat Neurosci 1999; 2: 941-943.

99 Dobolyi A, Ueda H, Uchida H, Palkovits M, Usdin TB. Anatomical and physiological evidence for involvement of tuberoinfundibular peptide of 39 residues in nociception. Proc Natl Acad Sci U S A 2002; 99: 1651-1656.

100 Dobolyi A, Wang J, Irwin S, Usdin TB. Postnatal development and gender-dependent expression of TIP39 in the rat brain. J Comp Neurol 2006; 498: 375-389.

101 Cservenak M, Bodnar I, Usdin TB, Palkovits M, Nagy GM, Dobolyi A. Tuberoinfundibular peptide of 39 residues is activated during lactation and participates in the suckling-induced prolactin release in rat. Endocrinology 2010; 151: 5830-5840.

102 Varga T, Mogyorodi B, Bago AG, Cservenak M, Domokos D, Renner E, Gallatz K, Usdin TB, Palkovits M, Dobolyi A. Paralemniscal TIP39 is induced in rat dams and may participate in maternal functions. Brain Struct Funct 2012; 217: 323-335.

103 Szabo FK, Snyder N, Usdin TB, Hoffman GE. A direct neuronal connection between the subparafascicular and ventrolateral arcuate nuclei in non-lactating female rats. Could this pathway play a role in the suckling-induced prolactin release? Endocrine 2010; 37: 62-70.

104 Palkovits M, Usdin TB, Makara GB, Dobolyi A. Tuberoinfundibular peptide of 39 residues- immunoreactive fibers in the zona incerta and the supraoptic decussations terminate in the neuroendocrine hypothalamus. Neurochem Res 2010; 35: 2078-2085.

105 Cservenak M, Szabo ER, Bodnar I, Leko A, Palkovits M, Nagy GM, Usdin TB, Dobolyi A. Thalamic neuropeptide mediating the effects of nursing on lactation and maternal motivation. Psychoneuroendocrinology 2013.

106 Coutellier L, Logemann A, Rusnak M, Usdin TB. Maternal absence of the parathyroid hormone 2 receptor affects postnatal pup development. J Neuroendocrinol 2011; 23: 612-619.

This article is protected by copyright. All rights reserved. 
107 Dobolyi A, Palkovits M, Usdin TB. The TIP39-PTH2 receptor system: unique peptidergic cell groups in the brainstem and their interactions with central regulatory mechanisms. Prog Neurobiol 2010; 90: 29-59.

108 Motomura K, Kosaka T. Medioventral part of the posterior thalamus in the mouse. $J$ Chem Neuroanat 2011; 42: 192-209.

$109 \mathrm{Li} \mathrm{C}$, Chen P, Smith MS. Neural populations in the rat forebrain and brainstem activated by the suckling stimulus as demonstrated by cFos expression. Neuroscience 1999; 94 : 117-129.

110 Bosch OJ, Musch W, Bredewold R, Slattery DA, Neumann ID. Prenatal stress increases HPA axis activity and impairs maternal care in lactating female offspring: implications for postpartum mood disorder. Psychoneuroendocrinology 2007; 32: 267-278.

111 Windle RJ, Wood S, Shanks N, Perks P, Conde GL, da Costa AP, Ingram CD, Lightman SL. Endocrine and behavioural responses to noise stress: comparison of virgin and lactating female rats during non-disrupted maternal activity. J Neuroendocrinol 1997; 9: 407-414.

112 Bosch OJ, Pfortsch J, Beiderbeck DI, Landgraf R, Neumann ID. Maternal behaviour is associated with vasopressin release in the medial preoptic area and bed nucleus of the stria terminalis in the rat. J Neuroendocrinol 2010; 22: 420-429.

113 Bosch OJ, Neumann ID. Brain vasopressin is an important regulator of maternal behavior independent of dams' trait anxiety. Proc Natl Acad Sci U S A 2008; 105: 17139-17144.

114 Eilam D, Smotherman WP. How the neonatal rat gets to the nipple: common motor modules and their involvement in the expression of early motor behavior. Dev Psychobiol 1998; 32: 57-66.

115 Walsh CJ, Fleming AS, Lee A, Magnusson JE. The effects of olfactory and somatosensory desensitization on Fos-like immunoreactivity in the brains of pupexposed postpartum rats. Behav Neurosci 1996; 110: 134-153.

116 Hashimoto H, Saito TR, Furudate S, Takahashi KW. Prolactin levels and maternal behavior induced by ultrasonic vocalizations of the rat pup. Exp Anim 2001; 50: 307312.

117 Okabe S, Nagasawa M, Kihara T, Kato M, Harada T, Koshida N, Mogi K, Kikusui T. Pup odor and ultrasonic vocalizations synergistically stimulate maternal attention in mice. Behav Neurosci 2013; 127: 432-438.

118 Terkel J, Damassa DA, Sawyer CH. Ultrasonic cries from infant rats stimulate prolactin release in lactating mothers. Horm Behav 1979; 12: 95-102.

This article is protected by copyright. All rights reserved. 
119 Campeau S, Watson SJ, Jr. Connections of some auditory-responsive posterior thalamic nuclei putatively involved in activation of the hypothalamo-pituitary-adrenocortical axis in response to audiogenic stress in rats: an anterograde and retrograde tract tracing study combined with Fos expression. J Comp Neurol 2000; 423: 474-491.

120 Fleming AS, Rosenblatt JS. Olfactory regulation of maternal behavior in rats. I. Effects of olfactory bulb removal in experienced and inexperienced lactating and cycling females. J Comp Physiol Psychol 1974; 86: 221-232.

121 Kinsley $\mathrm{CH}$, Bridges RS. Morphine treatment and reproductive condition alter olfactory preferences for pup and adult male odors in female rats. Dev Psychobiol 1990; 23: 331-347.

122 Levy F, Keller M. Olfactory mediation of maternal behavior in selected mammalian species. Behav Brain Res 2009; 200: 336-345.

123 Brunton PJ, Russell JA. The expectant brain: adapting for motherhood. Nat Rev Neurosci 2008; 9: 11-25.

124 Del Cerro MC, Perez Izquierdo MA, Rosenblatt JS, Johnson BM, Pacheco P, Komisaruk BR. Brain 2-deoxyglucose levels related to maternal behavior-inducing stimuli in the rat. Brain Res 1995; 696: 213-220.

125 Febo M, Numan M, Ferris CF. Functional magnetic resonance imaging shows oxytocin activates brain regions associated with mother-pup bonding during suckling. $J$ Neurosci 2005; 25: 11637-11644.

126 Lonstein JS, Simmons DA, Swann JM, Stern JM. Forebrain expression of c-fos due to active maternal behaviour in lactating rats. Neuroscience 1998; 82: 267-281.

127 Luckman SM. Fos expression within regions of the preoptic area, hypothalamus and brainstem during pregnancy and parturition. Brain Res 1995; 669: 115-124.

128 Fleming AS, Walsh C. Neuropsychology of maternal behavior in the rat: c-fos expression during mother-litter interactions. Psychoneuroendocrinology 1994; 19: 429-443.

129 Lonstein JS, De Vries GJ. Maternal behaviour in lactating rats stimulates c-fos in glutamate decarboxylase-synthesizing neurons of the medial preoptic area, ventral bed nucleus of the stria terminalis, and ventrocaudal periaqueductal gray. Neuroscience 2000; 100: 557-568.

130 Lonstein JS, Greco B, De Vries GJ, Stern JM, Blaustein JD. Maternal behavior stimulates c-fos activity within estrogen receptor alpha-containing neurons in lactating rats. Neuroendocrinology 2000; 72: 91-101.

This article is protected by copyright. All rights reserved. 
131 Kalinichev M, Rosenblatt JS, Nakabeppu Y, Morrell JI. Induction of c-fos-like and fosBlike immunoreactivity reveals forebrain neuronal populations involved differentially in pup-mediated maternal behavior in juvenile and adult rats. J Comp Neurol 2000; 416: 45-78.

132 Szabo ER, Cservenak M, Dobolyi A. Amylin is a novel neuropeptide with potential maternal functions in the rat. FASEB J 2012; 26: 272-281.

133 Stack EC, Numan M. The temporal course of expression of c-Fos and Fos B within the medial preoptic area and other brain regions of postpartum female rats during prolonged mother--young interactions. Behav Neurosci 2000; 114: 609-622.

134 Lin SH, Miyata S, Weng W, Matsunaga W, Ichikawa J, Furuya K, Nakashima T, Kiyohara T. Comparison of the expression of two immediate early gene proteins, FosB and Fos in the rat preoptic area, hypothalamus and brainstem during pregnancy, parturition and lactation. Neurosci Res 1998; 32: 333-341.

135 Brown JR, Ye H, Bronson RT, Dikkes P, Greenberg ME. A defect in nurturing in mice lacking the immediate early gene fosB. Cell 1996; 86: 297-309.

136 Kuroda KO, Meaney MJ, Uetani N, Fortin Y, Ponton A, Kato T. ERK-FosB signaling in dorsal MPOA neurons plays a major role in the initiation of parental behavior in mice. Mol Cell Neurosci 2007; 36: 121-131.

137 Driessen TM, Eisinger BE, Zhao C, Stevenson SA, Saul MC, Gammie SC. Genes showing altered expression in the medial preoptic area in the highly social maternal phenotype are related to autism and other disorders with social deficits. BMC Neurosci 2014; 15: 11.

138 Brooks PJ, Lund PK, Stumpf WE, Pedersen CA. Oxytocin Messenger Ribonucleic Acid Levels in the Medial Preoptic Area are Increased During Lactation. J Neuroendocrinol 1990; 2: 621-626.

139 Brooks PJ. The regulation of oxytocin mRNA levels in the medial preoptic area. Relationship to maternal behavior in the rat. Ann N Y Acad Sci 1992; 652: 271-285.

140 Knollema S, Brown ER, Vale W, Sawchenko PE. Novel hypothalamic and preoptic sites of prepro-melanin-concentrating hormone messenger ribonucleic Acid and Peptide expression in lactating rats. J Neuroendocrinol 1992; 4: 709-717.

141 Garcia MC, Lopez M, Gualillo O, Seoane LM, Dieguez C, Senaris RM. Hypothalamic levels of NPY, MCH, and prepro-orexin mRNA during pregnancy and lactation in the rat: role of prolactin. FASEB J 2003; 17: 1392-1400.

This article is protected by copyright. All rights reserved. 
142 Rondini TA, Donato J, Jr., Rodrigues Bde C, Bittencourt JC, Elias CF. Chemical identity and connections of medial preoptic area neurons expressing melanin-concentrating hormone during lactation. J Chem Neuroanat 2010; 39: 51-62.

143 Dobolyi A. Central amylin expression and its induction in rat dams. J Neurochem 2009; 111: 1490-1500.

144 Leffert JD, Newgard CB, Okamoto H, Milburn JL, Luskey KL. Rat amylin: cloning and tissue-specific expression in pancreatic islets. Proc Natl Acad Sci U S A 1989; 86: 3127-3130.

145 Dobolyi A. Novel potential regulators of maternal adaptations during lactation: tuberoinfundibular peptide 39 and amylin. J Neuroendocrinol 2011; 23: 1002-1008.

146 Driessen TM, Zhao C, Whittlinger A, Williams H, Gammie SC. Endogenous CNS Expression of Neurotensin and Neurotensin Receptors Is Altered during the Postpartum Period in Outbred Mice. PLoS One 2014; 9: e83098.

147 Gammie SC, Lee G, Scotti MA, Stevenson SA, Gessay GM. Neurotensin induced Egr-1 activity is altered in the postpartum period in mice. Brain Res 2012; 1433: 47-55.

148 da Costa AP, Ma X, Ingram CD, Lightman SL, Aguilera G. Hypothalamic and amygdaloid corticotropin-releasing hormone (CRH) and CRH receptor-1 mRNA expression in the stress-hyporesponsive late pregnant and early lactating rat. Brain Res Mol Brain Res 2001; 91: 119-130.

149 Pedersen CA, Caldwell JD, McGuire M, Evans DL. Corticotropin-releasing hormone inhibits maternal behavior and induces pup-killing. Life Sci 1991; 48: 1537-1546.

150 Pi X, Voogt JL. Effect of suckling on prolactin receptor immunoreactivity in the hypothalamus of the rat. Neuroendocrinology 2000; 71: 308-317.

151 Pi X, Voogt JL. Mechanisms for suckling-induced changes in expression of prolactin receptor in the hypothalamus of the lactating rat. Brain Res 2001; 891: 197-205.

152 Meddle SL, Bishop VR, Gkoumassi E, van Leeuwen FW, Douglas AJ. Dynamic changes in oxytocin receptor expression and activation at parturition in the rat brain. Endocrinology 2007; 148: 5095-5104.

153 Gammie SC, Hasen NS, Awad TA, Auger AP, Jessen HM, Panksepp JB, Bronikowski AM. Gene array profiling of large hypothalamic CNS regions in lactating and randomly cycling virgin mice. Brain Res Mol Brain Res 2005; 139: 201-211.

154 Du J, Yang YC. Cited2 in hematopoietic stem cell function. Curr Opin Hematol 2013; 20: 301-307.

This article is protected by copyright. All rights reserved. 
155 Oueslati A, Schneider BL, Aebischer P, Lashuel HA. Polo-like kinase 2 regulates selective autophagic alpha-synuclein clearance and suppresses its toxicity in vivo. Proc Natl Acad Sci U S A 2013; 110: E3945-3954.

156 Akbari EM, Shams S, Belay HT, Kaiguo M, Razak Z, Kent CF, Westwood T, Sokolowski MB, Fleming AS. The effects of parity and maternal behavior on gene expression in the medial preoptic area and the medial amygdala in postpartum and virgin female rats: A microarray study. Behav Neurosci 2013; 127: 913-922.

157 Franz JR, Leo RJ, Steuer MA, Kristal MB. Effects of hypothalamic knife cuts and experience on maternal behavior in the rat. Physiol Behav 1986; 38: 629-640.

158 Shams S, Pawluski JL, Chatterjee-Chakraborty M, Oatley H, Mastroianni A, Fleming AS. Dendritic morphology in the striatum and hypothalamus differentially exhibits experience-dependent changes in response to maternal care and early social isolation. Behav Brain Res 2012; 233: 79-89.

159 Kinsley CH, Lambert KG. Reproduction-induced neuroplasticity: natural behavioural and neuronal alterations associated with the production and care of offspring. $J$ Neuroendocrinol 2008; 20: 515-525.

160 Kim P, Leckman JF, Mayes LC, Feldman R, Wang X, Swain JE. The plasticity of human maternal brain: longitudinal changes in brain anatomy during the early postpartum period. Behav Neurosci 2010; 124: 695-700.

161 Fleming AS, Korsmit M. Plasticity in the maternal circuit: effects of maternal experience on Fos-Lir in hypothalamic, limbic, and cortical structures in the postpartum rat. Behav Neurosci 1996; 110: 567-582.

162 Akbari EM, Chatterjee D, Levy F, Fleming AS. Experience-dependent cell survival in the maternal rat brain. Behav Neurosci 2007; 121: 1001-1011.

163 Levenson JM, Sweatt JD. Epigenetic mechanisms in memory formation. Nat Rev Neurosci 2005; 6: 108-118.

164 Meaney MJ, Ferguson-Smith AC. Epigenetic regulation of the neural transcriptome: the meaning of the marks. Nat Neurosci 2010; 13: 1313-1318.

165 Riccio A. Dynamic epigenetic regulation in neurons: enzymes, stimuli and signaling pathways. Nat Neurosci 2010; 13: 1330-1337.

166 Cortes-Mendoza J, Diaz de Leon-Guerrero S, Pedraza-Alva G, Perez-Martinez L. Shaping synaptic plasticity: the role of activity-mediated epigenetic regulation on gene transcription. Int J Dev Neurosci 2013; 31: 359-369.

This article is protected by copyright. All rights reserved. 
167 Stolzenberg DS, Numan M. Hypothalamic interaction with the mesolimbic DA system in the control of the maternal and sexual behaviors in rats. Neurosci Biobehav Rev 2011; 35: 826-847.

168 Edwards DP. The role of coactivators and corepressors in the biology and mechanism of action of steroid hormone receptors. J Mammary Gland Biol Neoplasia 2000; 5: 307324.

169 Stolzenberg DS, McKenna JB, Keough S, Hancock R, Numan MJ, Numan M. Dopamine D1 receptor stimulation of the nucleus accumbens or the medial preoptic area promotes the onset of maternal behavior in pregnancy-terminated rats. Behav Neurosci 2007; 121: 907-919.

170 Numan M, Rosenblatt JS, Komisaruk BR. Medial preoptic area and onset of maternal behavior in the rat. J Comp Physiol Psychol 1977; 91: 146-164.

171 Stolzenberg DS, Stevens JS, Rissman EF. Experience-facilitated improvements in pup retrieval; evidence for an epigenetic effect. Horm Behav 2012; 62: 128-135.

172 Kuroda KO, Meaney MJ, Uetani N, Kato T. Neurobehavioral basis of the impaired nurturing in mice lacking the immediate early gene FosB. Brain Res 2008; 1211: 5771.

173 Jin SH, Blendy JA, Thomas SA. Cyclic AMP response element-binding protein is required for normal maternal nurturing behavior. Neuroscience 2005; 133: 647-655.

174 Stolzenberg DS, Grant PA, Bekiranov S. Epigenetic methodologies for behavioral scientists. Horm Behav 2011; 59: 407-416.

175 Champagne FA, Weaver IC, Diorio J, Dymov S, Szyf M, Meaney MJ. Maternal care associated with methylation of the estrogen receptor-alphalb promoter and estrogen receptor-alpha expression in the medial preoptic area of female offspring. Endocrinology 2006; 147: 2909-2915.

176 Haller J, Harold G, Sandi C, Neumann ID. Effects of adverse early-life events on agression and anti-social behaviours in animals and humans. $J$ Neuroendocrinol 2014: In press.

177 Maccari S, Krugers HJ, Morley-Fletcher S, Szyf M, Brunton PJ. The consequances of early life adversity: neurobiological, behavioural and epigenetic adaptations. $J$ Neuroendocrinol 2014: In press.

178 Roozendaal B, Hernandez A, Cabrera SM, Hagewoud R, Malvaez M, Stefanko DP, Haettig J, Wood MA. Membrane-associated glucocorticoid activity is necessary for

This article is protected by copyright. All rights reserved. 
modulation of long-term memory via chromatin modification. J Neurosci 2010; 30: 5037-5046.

179 Levenson JM, O'Riordan KJ, Brown KD, Trinh MA, Molfese DL, Sweatt JD. Regulation of histone acetylation during memory formation in the hippocampus. J Biol Chem 2004; 279: 40545-40559.

180 Korzus E, Rosenfeld MG, Mayford M. CBP histone acetyltransferase activity is a critical component of memory consolidation. Neuron 2004; 42: 961-972.

181 Danilova AB, Kharchenko OA, Shevchenko KG, Grinkevich LN. Histone H3 Acetylation is Asymmetrically Induced Upon Learning in Identified Neurons of the Food Aversion Network in the Mollusk Helix Lucorum. Front Behav Neurosci 2010; 4: 180.

182 Alarcon JM, Malleret G, Touzani K, Vronskaya S, Ishii S, Kandel ER, Barco A. Chromatin acetylation, memory, and LTP are impaired in $\mathrm{CBP}+/-$ mice: a model for the cognitive deficit in Rubinstein-Taybi syndrome and its amelioration. Neuron 2004; 42: 947-959.

183 Yeh SH, Lin CH, Gean PW. Acetylation of nuclear factor-kappaB in rat amygdala improves long-term but not short-term retention of fear memory. Mol Pharmacol 2004; 65: 1286-1292.

184 Hollis F, Wang H, Dietz D, Gunjan A, Kabbaj M. The effects of repeated social defeat on long-term depressive-like behavior and short-term histone modifications in the hippocampus in male Sprague-Dawley rats. Psychopharmacology (Berl) 2010; 211: 69-77.

185 Vecsey CG, Hawk JD, Lattal KM, Stein JM, Fabian SA, Attner MA, Cabrera SM, McDonough CB, Brindle PK, Abel T, Wood MA. Histone deacetylase inhibitors enhance memory and synaptic plasticity via CREB:CBP-dependent transcriptional activation. J Neurosci 2007; 27: 6128-6140.

186 Stefanko DP, Barrett RM, Ly AR, Reolon GK, Wood MA. Modulation of long-term memory for object recognition via HDAC inhibition. Proc Natl Acad Sci U S A 2009; 106: 9447-9452.

187 Malvaez M, Sanchis-Segura C, Vo D, Lattal KM, Wood MA. Modulation of chromatin modification facilitates extinction of cocaine-induced conditioned place preference. Biol Psychiatry 2010; 67: 36-43.

188 Zhao Z, Fan L, Frick KM. Epigenetic alterations regulate estradiol-induced enhancement of memory consolidation. Proc Natl Acad Sci U S A 2010; 107: 5605-5610.

This article is protected by copyright. All rights reserved. 
189 Zhao Z, Fan L, Fortress AM, Boulware MI, Frick KM. Hippocampal histone acetylation regulates object recognition and the estradiol-induced enhancement of object recognition. J Neurosci 2012; 32: 2344-2351.

190 Frick KM, Zhao Z, Fan L. The epigenetics of estrogen: epigenetic regulation of hormoneinduced memory enhancement. Epigenetics 2011; 6: 675-680.

\section{Figure legends}

Fig. 1. Prolactin receptors are widely expressed in the MPOA. The figure (top panel, left) shows $\mathrm{S}^{35}$-labelling of prolactin receptor mRNA by in situ hybridisation, showing strong labelling (black dots) over numerous neurones (blue counterstain) in the MPOA. The inset shows autoradiographic film of the section, with extensive expression evident throughout the MPOA (including vBNST) as well as lateral septum and choroid plexus (dark staining within the lateral ventricles). Remaining panels illustrate prolactin-induced phosphorylation of STAT5 in the MPOA using immunohistochemistry (black nuclear staining), with a prolactinsensitive gonadotrophin-releasing hormone neuron labelled (brown staining) as an example of a prolactin-sensitive neuron. Data are from $(67,68)$.

Fig. 2. The projection from the posterior intralaminar complex of the thalamus (PIL) to the medial preoptic area (MPOA). A: The distribution of fibre terminals containing tuberoinfundibular peptide of 39 residues (Tip39) in the MPOA. Small dots in the drawing on the right represent Tip39 fibre terminals. B: Tip39-immunoreactive cell bodies in the PIL. Large dots on the right represent Tip39-expressing neurones. The drawing shows the projection of these neurones to the MPOA.

Fig. 3. Histone deacetylase inhibition (HDACi) potentiates maternal responsiveness. Virgin mice with no experience or sub-threshold experience (2 exposures) were not responsive to infants on the maze, but threshold experience (4 exposures) resulted in similar behaviour as postpartum mice. Administration of an HDACi reduced the amount of experience required to induce pup retrieval on the maze. Exposure to foster pups lasted for 2 hours and each exposure was separated by 24-hours. T-maze testing took place 24 hours after the last exposure. Virgin mice were ovary intact. Data comparing the effects of maternal experience on pup retrieval in the T-maze in virgin versus postpartum mice were adapted from (174).

This article is protected by copyright. All rights reserved. 
Data comparing the effects of maternal experience on pup retrieval in the T-maze after HDACi administration or control were adapted from (171). All data are presented as Mean \pm SEM.

Fig. 4. (A)-(B) No effect of HDACi-treatment on gene expression in MPOA or pup retrieval on T-maze 5h after pup experience [unpublished data]. (C)-(D) HDACi treatment effects gene expression and pup retrieval $24 \mathrm{~h}$ after pup experience (171). (E)-(F) HDACi during subthreshold pup experience maintains pup retrieval responses along with Esr2 expression 1 month later [manuscript under review].\{Stolzenberg, $2012 \# 152\}$

\section{Prolactin receptor mRNA in MPOA (in situ hybridisation)}
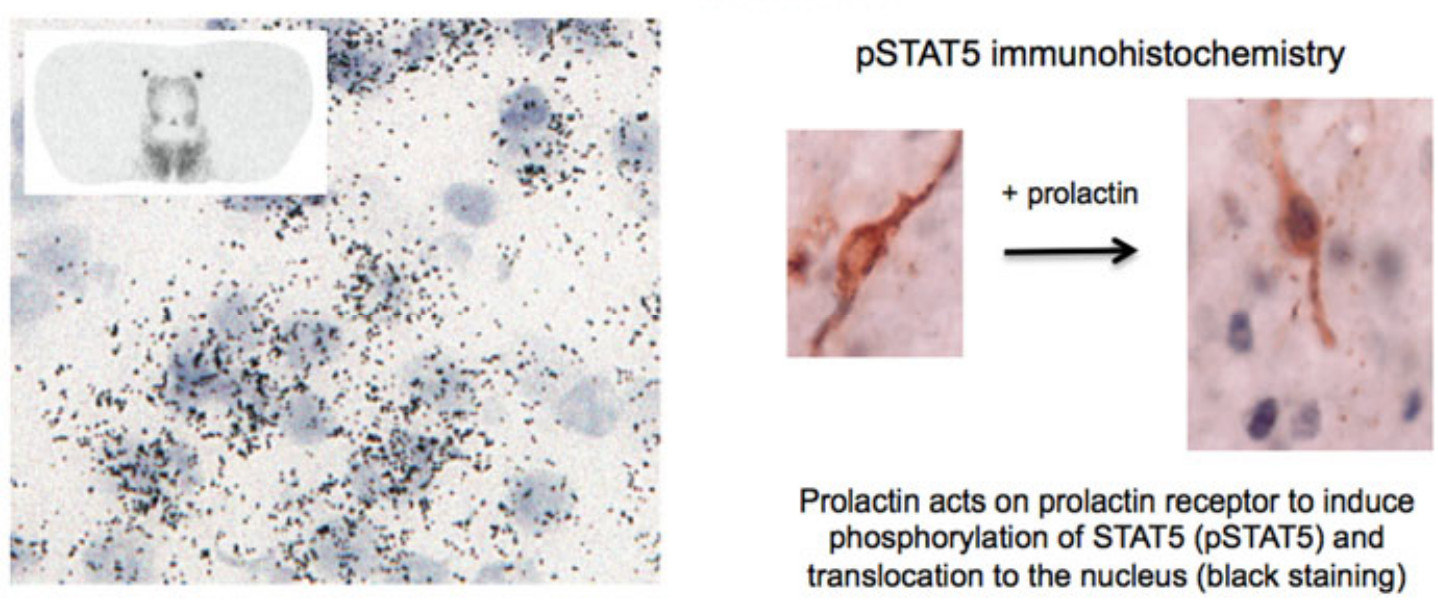

pSTAT5 immunohistochemistry in MPOA
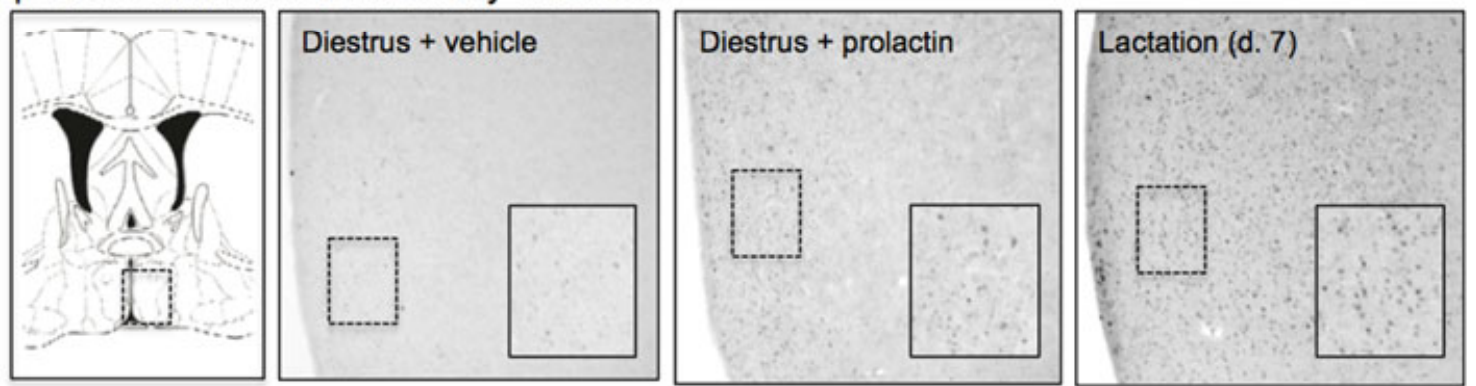

This article is protected by copyright. All rights reserved. 


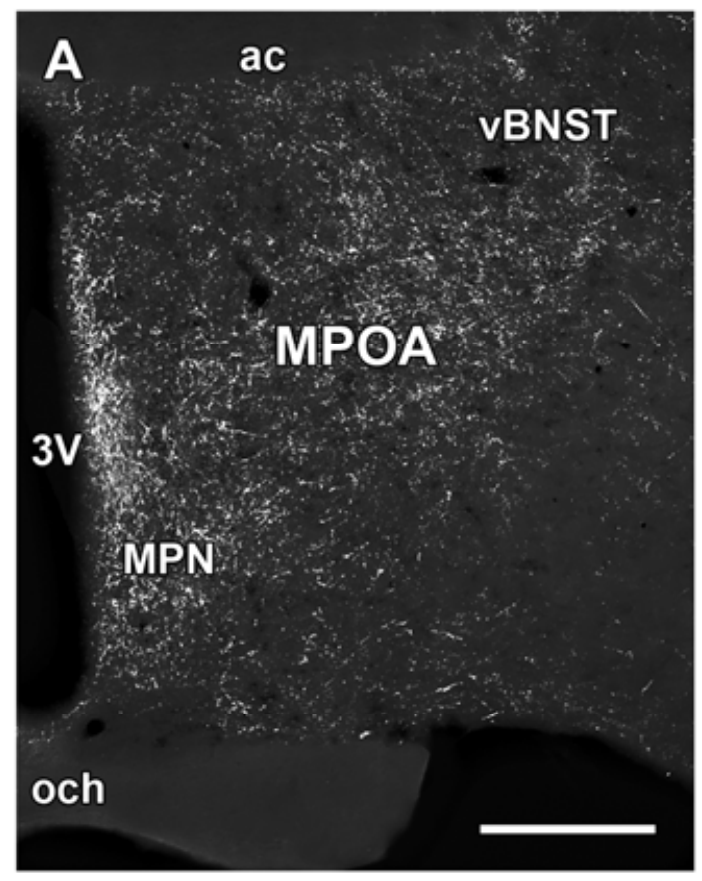

Medial preoptic area (MPOA)
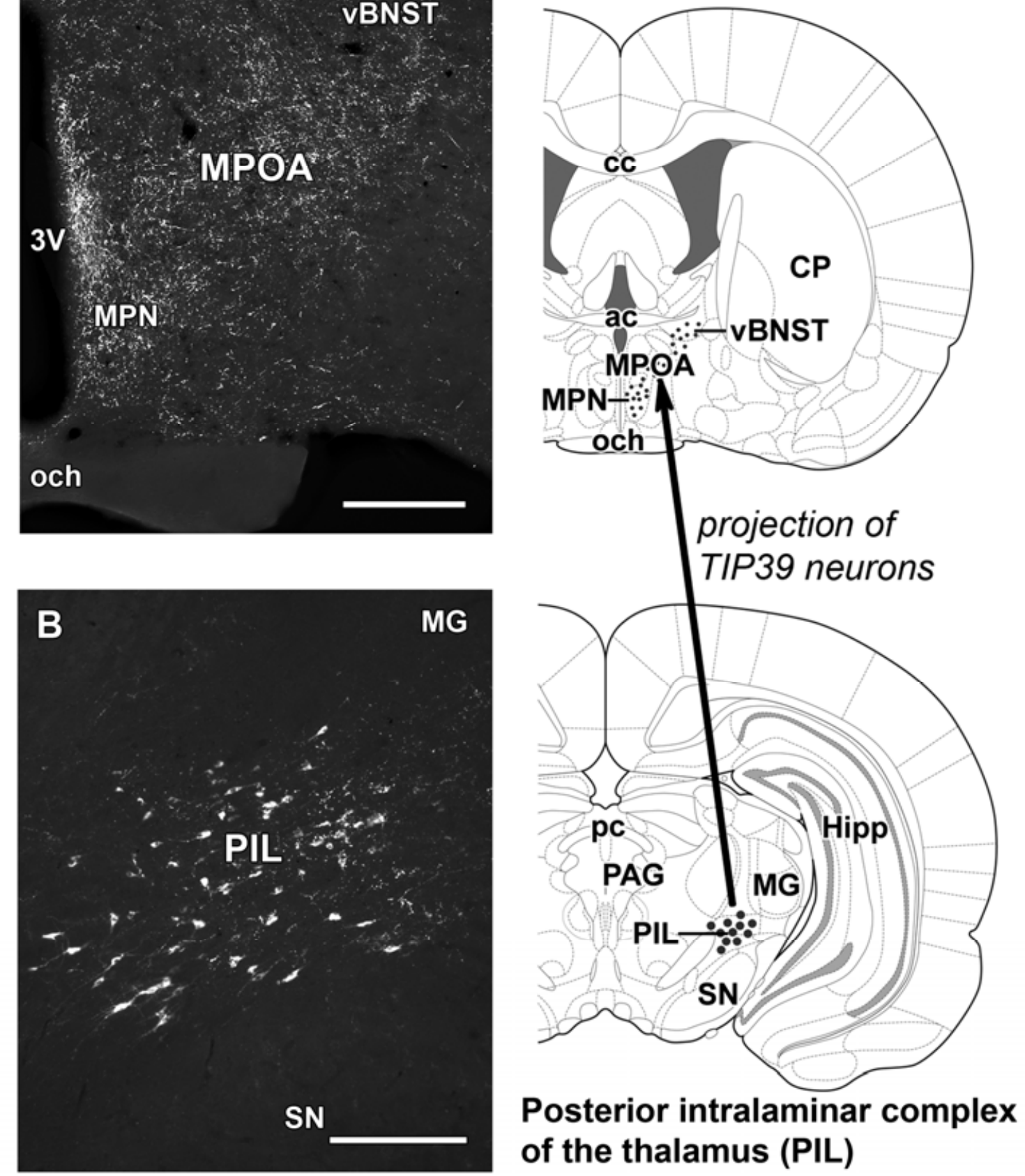

This article is protected by copyright. All rights reserved. 


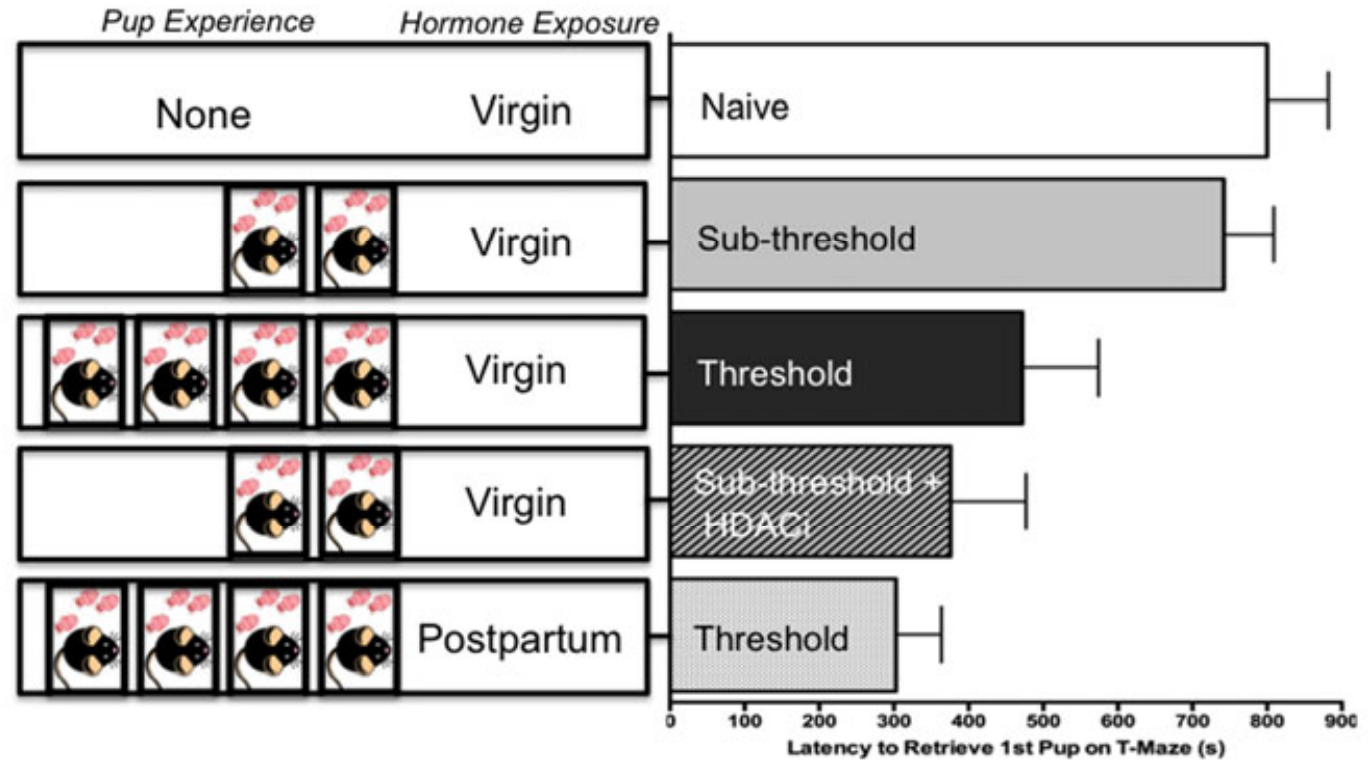

This article is protected by copyright. All rights reserved. 
Timing of Gene Expression Linked to Maternal Responses on Maze 5 hours after pupexperience

A.

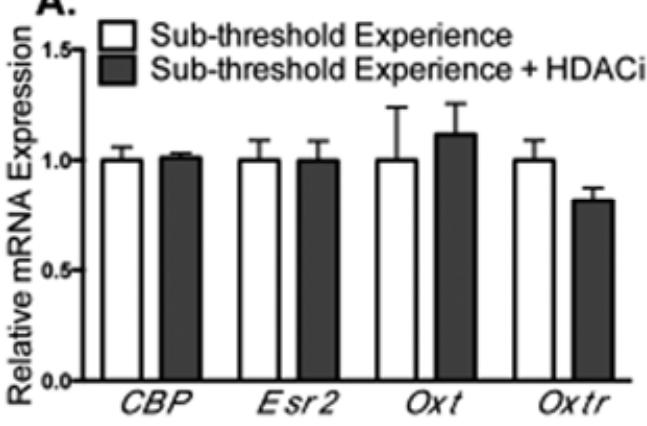

B.

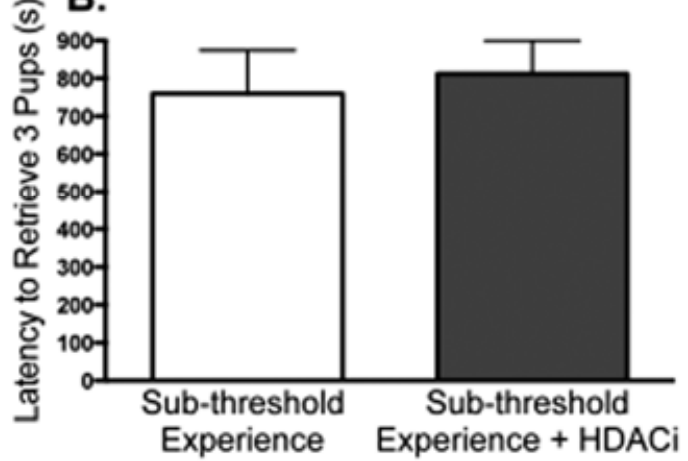

24 hours after pupexperience
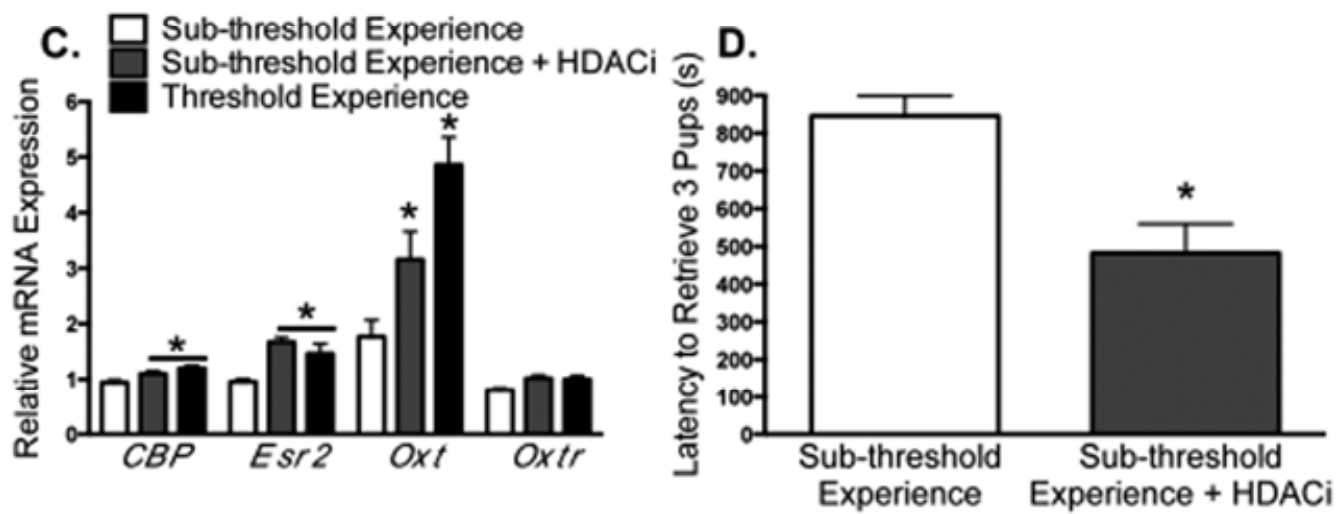

1 month after pupexperience
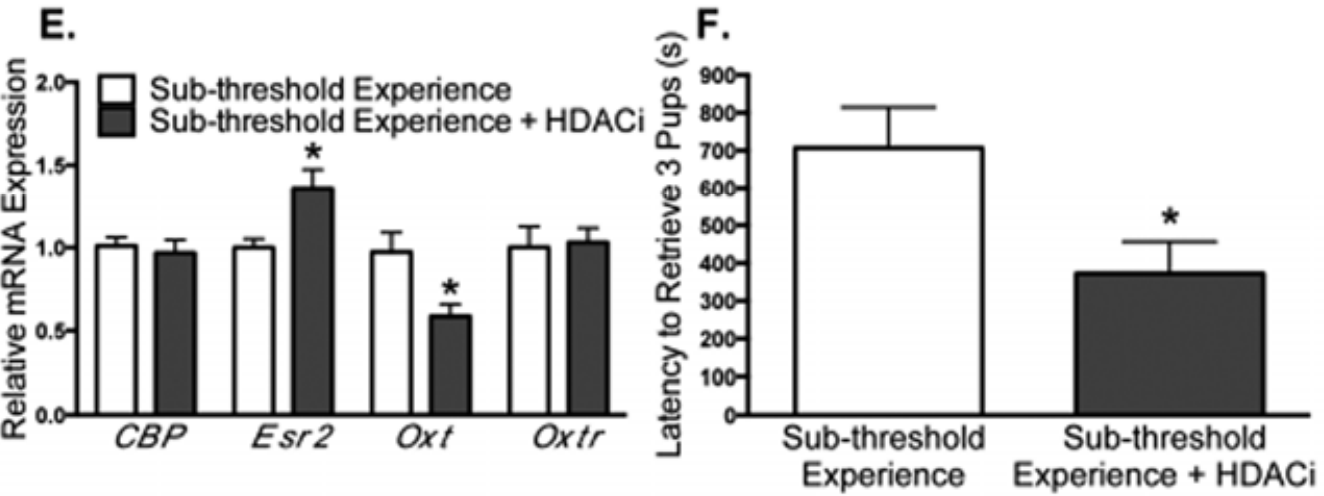

This article is protected by copyright. All rights reserved. 